Journal of Materials and

Environmental Sciences

ISSN : 2028-2508

CODEN : JMESCN

Copyright $\odot 2017$

University of Mohammed Premie

Oujda Morocco
J. Mater. Environ. Sci., 2017, Volume 8, Issue 12, Page 4573-4581

http://www.jmaterenvironsci.com

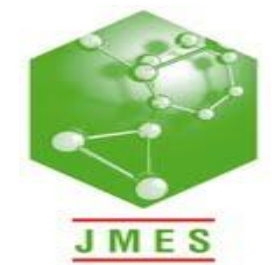

\title{
Study of Methylene Blue Removal by a biosorbent prepared with Apple peels
}

\author{
I. Enniya*, A. Jourani \\ Laboratory of Physical Chemistry of Processes and Materials (PCPM), University Hassan $1^{\text {st }}$, FST Settat, Morocco
}

Received: 26 Avr 2016

Revised: 9 Nov 2016

Accepted: 16 Nov 2016

Keywords

$\checkmark$ Adsorption;

$\checkmark$ Methylene Blue;

$\checkmark$ Apple peel;

$\checkmark$ Isotherms;

$\checkmark$ Kinetics;

$\checkmark$ Thermodynamics

I ENNIYA

enniya.imane@gmail.com $+212676365554$

\begin{abstract}
This work investigates the removal of the methylene blue by adsorption using dried apple peels. For this purpose, various experimental parameters were studied: $\mathrm{pH}$ [3-10], adsorbent dose [0.25- $3 \mathrm{~g} / \mathrm{L}]$, solution temperature [10$\left.40^{\circ} \mathrm{C}\right]$ and initial concentration of methylene blue [10- $\left.345 \mathrm{mg} / \mathrm{L}\right]$. Adsorption data were modeled using Langmuir, Freundlich and Temkin adsorption isotherms. The results indicated that the equilibrium data was well represented by Langmuir isotherm with $\mathrm{R}^{2}=0.99$. The maximum adsorption capacity is $107.52 \mathrm{mg} / \mathrm{g}$. The Kinetics of methylene blue adsorption using apple peels is described by the pseudo-second order model. In addition, the thermodynamic parameters such as $\Delta \mathrm{H}^{\circ}, \Delta \mathrm{S}^{\circ}$ and $\Delta \mathrm{G}^{\circ}$ were determined, and the dye adsorption process is exothermic.
\end{abstract}

\section{Introduction}

Everything in our world is colored, our clothing, our food, our cosmetics and pharmaceutics etc.These dyes are increasingly synthetic due to their facility of synthesis, their timeliness of production and their variety of colors in comparison with natural dyes [1]. To this end, textile industry produces huge amounts of waste water loaded with dyes. These dyes can be classified as anionic dyes, cationic dyes and no ionic dyes. Cationic dyes are the most toxic ones [2]. They have harmful effects on the environment such as: eutrophication, under-oxidation, resistance to organic biodegradation, bioaccumulation, mutagenicity and carcinogenicity [1].

In this regard, the treatment of waste water containing dyes has become a necessity.

A wide variety of physical, chemical and biological techniques has been introduced for the treatment of these effluents. These techniques are: coagulation-flocculation, membrane filtration, adsorption, oxidation and reduction [1].

Adsorption is relatively an easy technique to implement. Activated carbon is the most used adsorbent due to its high adsorption capacity [3]. But this later is very expensive, so research for other effective and cheaper adsorbents turns out interesting. Many adsorbents are widely used for adsorption of dyes such as clays [4], [5], [6]and agricultural waste specially fruit and vegetable peels. Several bioadsorbents were used for removal of textile dyes, for example: orange peel [7], [8], banana peel [9], pomelo peel [10], jack fruit peel [11], potato peel [12], melon peel [13] and cucumber peel [14].

Apple peels are produced in large amount in the worldwide as biowaste from food processing industries and offer abundant functional groups which can be exploited for water treatment.

The purpose of this work is the evaluation of adsorption capacity of a new adsorbent prepared from apple peels without any chemical treatment, by removal ofmethylene blue, which is most commonly used in dyeing in the textile industry, in biology and as an antiseptic in pharmacy.

Various experimental parameters were studied: $\mathrm{pH}$, adsorbent dosage,initial dye concentration and temperature. Kinetics, adsorption isotherms and thermodynamic parametersof the adsorption of MB on dried apple peel were also studied. 


\section{Materials and methods}

\subsection{Adsorbent Preparation}

Apples (Golden Delicious) were purchased from the local market. They were peeled and peelsdevoid of pulp were dried at a temperature of $60{ }^{\circ} \mathrm{C}$ for $24 \mathrm{~h}$. Driedapple peels (DAP) were ground and sieved in order to obtain particles size inferior to $250 \mu \mathrm{m}$. The adsorbent is stored in closed container at room temperature.

\subsection{Adsorbate}

Methylene blue (MB) is a cationic dye of the thiazine class. It has the formula of $\mathrm{C}_{16} \mathrm{H}_{18} \mathrm{~N}_{3} \mathrm{SCl}$, a molecular weight of $319.85 \mathrm{~mol} / \mathrm{g}$ and its solubility in water exceeds $100 \mathrm{mg} / \mathrm{L}$ [15]. A stock solution $(1 \mathrm{~g} / \mathrm{L})$ was prepared. To prepare various solutions at desired concentrations from the stock solution, distilled water was used for the necessary dilutions. Concentration of solutions was analyzed by measuring the absorbance values with a spectrophotometer at $664 \mathrm{~nm}$.

\subsection{Adsorbent characterization}

\subsubsection{Fourier transform infrared spectroscopy (FTIR)}

Fourier transform infrared spectroscopy of the adsorbent was done by using an FTIR spectrophotometer in therange from 600 to $4000 \mathrm{~cm}^{-1}$, in order to determine the functional groups present in the DAP surface.

\subsubsection{Point of zero charge $\left(p H_{p z c}\right.$ ) of DAP}

$\mathrm{pH}_{\mathrm{pzc}}$ is one of adsorbent characteristics. It was estimated by introducing $0.5 \mathrm{~g}$ of DAP in $50 \mathrm{~mL}$ of distilled water at initial $\mathrm{pH}$ values of $3,4,6,8$ and 10 adjusted by adding required amounts of $\mathrm{NaOH}(0.1 \mathrm{~N})$ or $\mathrm{HCl}(0.1$ $\mathrm{N})$. The mixture was stirred for 24 hours at room temperature, and the final $\mathrm{pH}$ was measured [16].

The intersection between the first bisectrix and the curve representing the variation of the final $\mathrm{pH}$ with the initial $\mathrm{pH}$ gives a $\mathrm{pH}_{\mathrm{pzc}}$ equal to 5.8.

\subsection{Adsorption studies}

Adsorption experiments were carried out by introducing a quantity of the adsorbent in $1 \mathrm{~L}$ of methylene blue solution at initialconcentration and at the desired temperaturemaintained with a thermostated bath. The mixture was stirred on an electromagnetic stirrer at a constant speed(400 rpm). The controlled parameters are: initial concentration of $\mathrm{MB}, \mathrm{pH}$, temperatureand adsorbent dose. Samples of the solution were withdrawn at various time intervalsand centrifuged at $2000 \mathrm{rpm}$ for one minute. The supernatant absorbance is measured using the spectrophotometer at $664 \mathrm{~nm}$. The removal percentage (\%R) of methylene blue is calculated as follows:

$$
\% R=\frac{C_{i}-C_{e}}{C_{i}} \times 100(1)
$$

$\mathrm{C}_{\mathrm{i}}(\mathrm{mg} / \mathrm{l})$ is the initial concentration of $\mathrm{MB}, \mathrm{C}_{\mathrm{e}}(\mathrm{mg} / \mathrm{L})$ is the dye concentration at equilibrium.

Adsorption capacity of methylene blue is given by the following formula:

$$
\mathrm{q}_{\mathrm{t}}=\frac{\left(\mathrm{C}_{\mathrm{i}}-\mathrm{C}_{\mathrm{t}}\right) \times \mathrm{V}}{\mathrm{m}}(2)
$$

$\mathrm{q}_{\mathrm{t}}(\mathrm{mg} / \mathrm{g})$ is the amount adsorbed at time $\mathrm{t}(\mathrm{min}), \mathrm{C}_{\mathrm{t}}(\mathrm{mg} / \mathrm{L})$ is the dye concentration at time $\mathrm{t}$;

$\mathrm{V}(\mathrm{L})$ is the volume of dye solution and $\mathrm{m}(\mathrm{g})$ is the mass of theadsorbent used.

\section{Theory and calculation}

\subsection{Adsorption isotherms}

The study of adsorption isotherm is necessary in order to understand the adsorption mechanism. In the present investigation the experimental data were modeled using Langmuir, Freundlich and Temkin isotherm

\subsubsection{Langmuir isotherm}

Langmuir theory assumes [17]:

- Adsorbent has a limited adsorption capacity $\left(\mathrm{q}_{\max }\right)$

- Adsorbate forms a monolayer on the adsorbent surface

- Active sites are identical

- Absence of interaction between the adsorbed molecules.

Langmuir isotherm is given by the following equation:

$$
q_{e=} \frac{q_{\max } K_{L} C_{e}}{1+K_{L} C_{e}}(3)
$$

$\mathrm{C}_{\mathrm{e}}(\mathrm{mg} / \mathrm{L})$ is the concentration of the adsorbate in solution at equilibrium, $\mathrm{q}_{\mathrm{e}}(\mathrm{mg} / \mathrm{g})$ is the adsorbed amount at equilibrium, $\mathrm{q}_{\max }(\mathrm{mg} / \mathrm{g})$ is the maximum amount adsorbed, $\mathrm{K}_{\mathrm{L}}(\mathrm{L} / \mathrm{mg})$ is the Langmuir constant.

Its linear form is: 
3.1.2. Freundlich isotherm

$$
\frac{C_{e}}{q_{e}}=\frac{1}{q_{\max } K_{L}}+\frac{C_{e}}{q_{\max }}
$$

Freundlich model [18], is applied in the case of multilayer adsorption. However, this model assumes the existence of interactions between adsorbed molecules. Freundlich isotherm model can be defined by the following equation:

$$
q_{e}=K_{F} C_{e}^{1 / n}
$$

$\mathrm{q}_{\mathrm{e}}(\mathrm{mg} / \mathrm{g})$ is the adsorbed amount at equilibrium, $\mathrm{C}_{\mathrm{e}}(\mathrm{mg} / \mathrm{L})$ is the concentration of the adsorbate in the solution at equilibrium, $\mathrm{k}_{\mathrm{F}}$ is the Freundlich constant, $\mathrm{n}$ is the adsorption intensity.

Its linear form is given by the following equation:

\subsubsection{Temkin isotherm}

$$
\ln q_{e}=\ln K_{F}+\frac{1}{n} \ln C_{e}
$$

Temkin's model is based on the hypothesis that the heat of adsorption due to interactions with the adsorbate decreases linearly with the recovery rate, whiting gas phase adsorption. This is an application of the Gibbs relation to the adsorbents, whose surface is considered homogeneous energy.

Several authors [19], [20] proposed to use this model in the liquid phase.

Temkin equation is given by the following expression:

$$
\frac{q_{e}}{q_{\max }}=\frac{R T}{\Delta Q} \ln \left(K_{T} \cdot C_{e}\right)
$$

$\mathrm{q}_{\mathrm{e}}(\mathrm{mg} / \mathrm{g})$ is the adsorbed amount at equilibrium, $\mathrm{q}_{\max }(\mathrm{mg} / \mathrm{g})$ is the maximum amount adsorbed, $\mathrm{T}(\mathrm{K})$ is the absolute temperature, $\Delta \mathrm{Q}(\mathrm{J} / \mathrm{mol})$ is the variation in adsorption energy $\mathrm{K}_{\mathrm{T}}(\mathrm{L} / \mathrm{mg})$ is the Temkin constant.

The Temkin equation can be written:

$$
\begin{aligned}
& q_{e}=B \ln K_{T}+B \ln C_{e} \\
& B=q_{\text {max }} \frac{R T}{\Delta Q}
\end{aligned}
$$

\section{Results and discussion}

\subsection{FTIR characterization of DAP}

The FTIR spectrum of dried apple peels before and after methylene blue adsorption is shown in Figure 1.
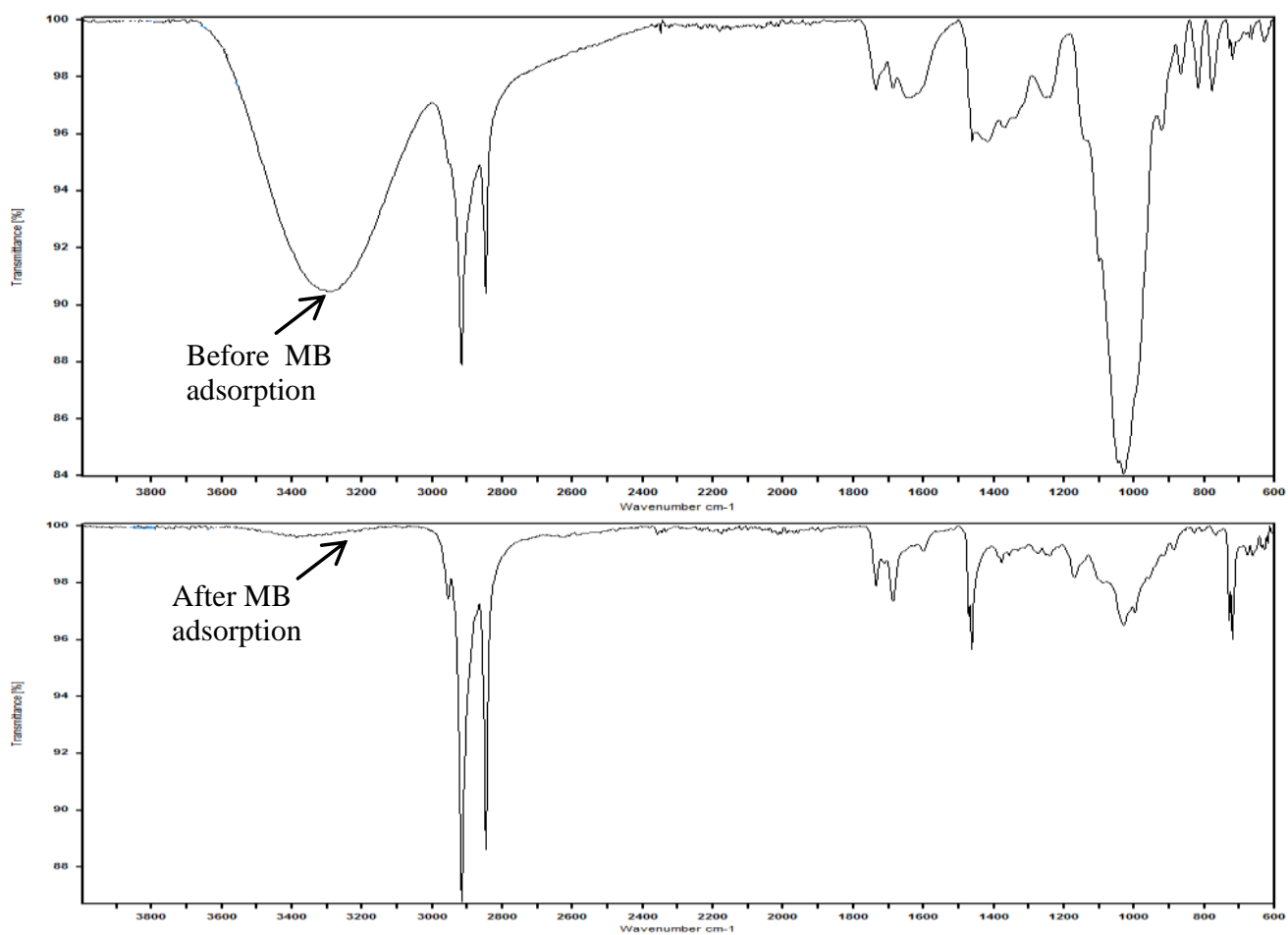

Figure 1: FTIR spectra of DAP before and after MB adsorption 
From Table 1 we can see that $-\mathrm{OH}$ groups, $\mathrm{C}=\mathrm{O}$ group of carbonyl, carboxyl groups,C-O-C group andC-O groups disappeared in the FTIR spectra of DAP after adsorption of methylene blue. While $\mathrm{C}=\mathrm{O}$ groups of esters, asymmetric and symmetric stretching of $-\mathrm{C}-\mathrm{H}$ in $-\mathrm{CH}_{2}$ groups, $\mathrm{C}-\mathrm{O}-\mathrm{C}$ group of etherand $\mathrm{C}=\mathrm{O}$ groups shifted in positions. So we can conclude that $\mathrm{MB}$ binding mostly at $\mathrm{OH}, \mathrm{C}-\mathrm{O}, \mathrm{C}-\mathrm{O}-\mathrm{C}$ and $\mathrm{C}=\mathrm{O}$ groups.

Table 1: FTIR peaks of DAP before and after adsorption of MB

\begin{tabular}{|c|c|c|c|}
\hline $\begin{array}{l}\text { Peaks before } \\
\text { adsorption }\end{array}$ & $\begin{array}{l}\text { Peaks after } \\
\text { adsorption }\end{array}$ & Difference & Functional groups \\
\hline $\begin{array}{r}2916.88 \\
2848.90 \\
1736.62 \\
1687.07 \\
1645.25 \\
\\
1461.68 \\
1417.88 \\
1368.43 \\
1254.18 \\
\\
1099.85 \\
1047.04 \\
1029.04 \\
866.71 \\
817.66 \\
777.89\end{array}$ & $\begin{array}{l}\text { disappear } \\
2955.33 \\
2915.88 \\
2848.24 \\
1736.25 \\
1687.16 \\
\text { disappear } \\
1472.07 \\
1462.27 \\
\text { Disappear } \\
1377.20 \\
1239.62 \\
1170.32 \\
\text { Disappear } \\
\text { Disappear } \\
1028.80 \\
\text { Disappear } \\
\text { disappear } \\
\text { disappear } \\
\text { 677.40 }\end{array}$ & $\begin{array}{l}\text { unknown } \\
\text { Appear } \\
-1 \\
-0.66 \\
-0.37 \\
+0.9 \\
\text { unknown } \\
\text { Appear } \\
+0.59 \\
\text { unknown } \\
+8.77 \\
-14.56 \\
\text { Appear } \\
\text { unknown } \\
-0.24 \\
\text { Unknown } \\
\text { Unknown } \\
\text { Unknown }\end{array}$ & $\begin{array}{l}\text {-OH group } \\
\text { Stretchingin sym andasym of }-\mathrm{CH} \text { aliphatic } \\
-\mathrm{C}-\mathrm{H} \text { stretching inasym in }-\mathrm{CH}_{2} \text { group } \\
-\mathrm{C}-\mathrm{H} \text { stretching inasym in }-\mathrm{CH}_{2} \text { group } \\
-\mathrm{C}=\mathrm{O} \text { of ester group } \\
-\mathrm{C}=\mathrm{O} \text { group of carbonyl (amide) } \\
-\mathrm{C}=\mathrm{O} \text { group of carbonyl } \\
\text { Stretching of } \mathrm{C}=\mathrm{C} \text { bond in aromatic rings } \\
\text { Stretching of } \mathrm{C}=\mathrm{C} \text { bond in aromatic rings } \\
\text { Carboxyl groups } \\
-\mathrm{C}-\mathrm{O}-\mathrm{C} \text { group of ether } \\
-\mathrm{C}-\mathrm{O}-\mathrm{C} \text { group of ether } \\
-\mathrm{C}=\mathrm{S} \text { group } \\
-\mathrm{C}-\mathrm{O} \text { group } \\
-\mathrm{C}-\mathrm{O}-\mathrm{C} \text { group } \\
-\mathrm{C}=\mathrm{O} \text { groups } \\
\text { Deformation of aromatic rings } \\
\text { Deformation of aromatic rings } \\
\mathrm{S}=\mathrm{O} \\
\mathrm{C}-\mathrm{Cl}\end{array}$ \\
\hline
\end{tabular}

\subsection{Effect of adsorbent dose}

To study the effect of DAP dose on the removal of methylene blue in aqueous solution, experiments were conducted using $1 \mathrm{~L}$ of methylene blue solution at initial concentration of $10 \mathrm{mg} / \mathrm{L}$ to which different quantities of DAP were added: $0.25,0.5,1,2$ and $3 \mathrm{~g}$. Figure 2 shows the evolution of the adsorption percentage of the $\mathrm{MB}$ and of the MB adsorbed quantity $(\mathrm{mg} / \mathrm{g})$ as a function of the dose of DAP.

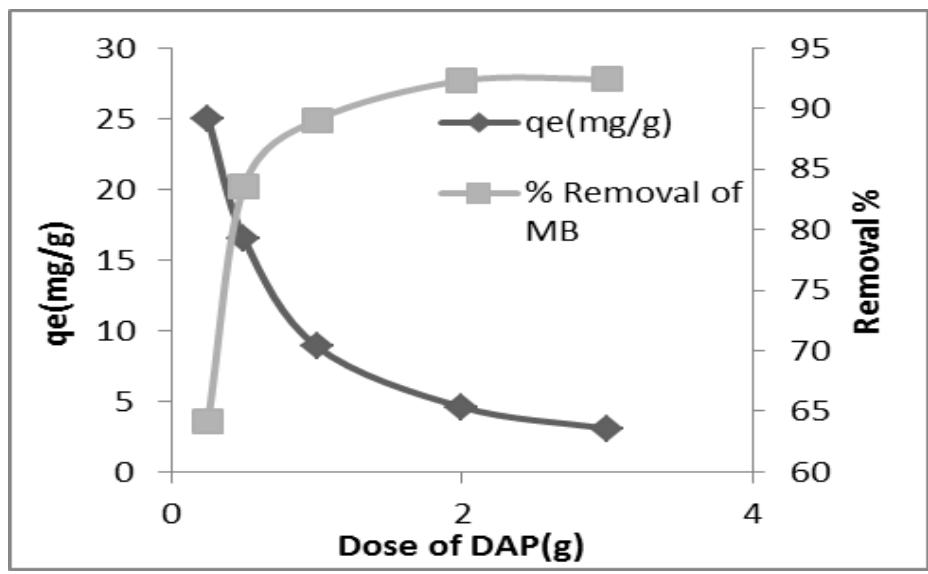

Figure 2: Effect of adsorbent dose on $\mathrm{MB}$ adsorption onto DAP

(MB Initial concentration $=10 \mathrm{mg} / \mathrm{L}, \mathrm{T}=20^{\circ} \mathrm{C}, \mathrm{pH}=6$, time $=6$ hours)

The results (Figure 2) indicate that adsorption percentage of MB increases with the increasing of adsorbent dose, it increased from $64 \%$ for $0.25 \mathrm{~g}$ to $92 \%$ for $2 \mathrm{~g}$. This is due to the number of active sites that increases with increasing of adsorbent dose. While the amount of MB adsorbed $(\mathrm{mg} / \mathrm{g}$ ) decreased from $25.03 \mathrm{mg} / \mathrm{g}$ for $0.25 \mathrm{~g}$ to $4.58 \mathrm{mg} / \mathrm{g}$ for $2 \mathrm{~g}$. When the mass exceeds $2 \mathrm{~g}$, the percentage of MB removed and adsorbed amount does not change significantly. 


\subsection{Effect of $\mathrm{pH}$}

$\mathrm{pH}$ is an important factor in adsorption study, because it can influence the adsorption mechanism.For this reason, the behavior of adsorption as a function of $\mathrm{pH}$ was studied in a $\mathrm{pH}$ range of 3 to 10. Figure 3 shows the effect of $\mathrm{pH}$ on methylene blue adsorption.As shown in Figure 3, the adsorption capacity $(\mathrm{mg} / \mathrm{g})$ increases in the $\mathrm{pH}$ range of 3-6, then the amount becomes constant within the range of 6-10.

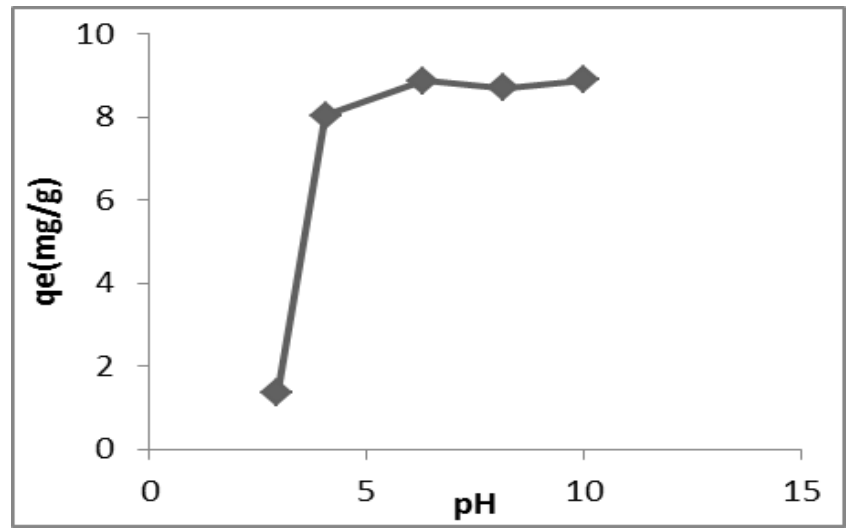

Figure 3: Effect of $\mathrm{pH}$ on $\mathrm{MB}$ adsorption onto DAP (MB concentration $10 \mathrm{mg} / \mathrm{L}, \mathrm{T}=20^{\circ} \mathrm{C}$, DAP dose $=1 \mathrm{~g}$, time $=6$ hours $)$

Methylene blue is a cationic dye; its adsorption is influenced by the adsorbent surface charge, which is influenced by the solutionpH. According to Uddinet al. [21] and[22], at $\mathrm{pH}<\mathrm{pH}_{\mathrm{pzc}}$, adsorbent surface is positively charged due to the fixation of $\mathrm{H}^{+}$ions (protonation of amine groups(equation (10)). The $\mathrm{pH}_{\mathrm{pzc}} \mathrm{Of} \mathrm{DAP}$ is 5.8, which causes repulsion between $\mathrm{MB}$ and adsorption sites at $\mathrm{pH}<\mathrm{pH}_{\mathrm{pzc}}$. At $\mathrm{pH}>\mathrm{pH}_{\mathrm{pzc}}, \mathrm{OH}^{-}$ions concentration increases leading to deprotonation of the carboxyl groups (equation (11) and equation (12)), and theadsorbent surface becomes negatively charged. So there is an attraction between MB and adsorbent surface. This explains the increase in the quantities adsorbed in comparisonwith those observed at $\mathrm{pH}<\mathrm{pH}_{\mathrm{pzc}}$ (Figure 3 ).

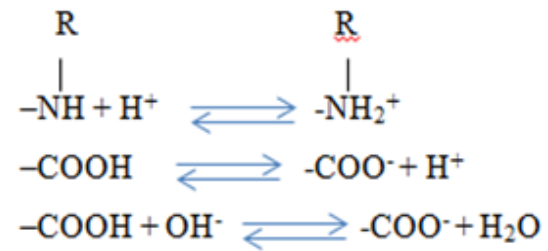

\subsection{Effect of initial dye concentration}

The effect of initialdye concentration was studied by introducing $1 \mathrm{~g}$ of DAP in $1 \mathrm{~L}$ of MB solution at different concentrations: $10,20,40,54,100$ and $345 \mathrm{mg} / \mathrm{L}$, at a temperature of $20^{\circ} \mathrm{C}$, a pH of 6 and a contact time of 6 hours. Figure 4 represents the adsorption capacity $(\mathrm{mg} / \mathrm{g})$ versus the contact time for different initial concentrations.

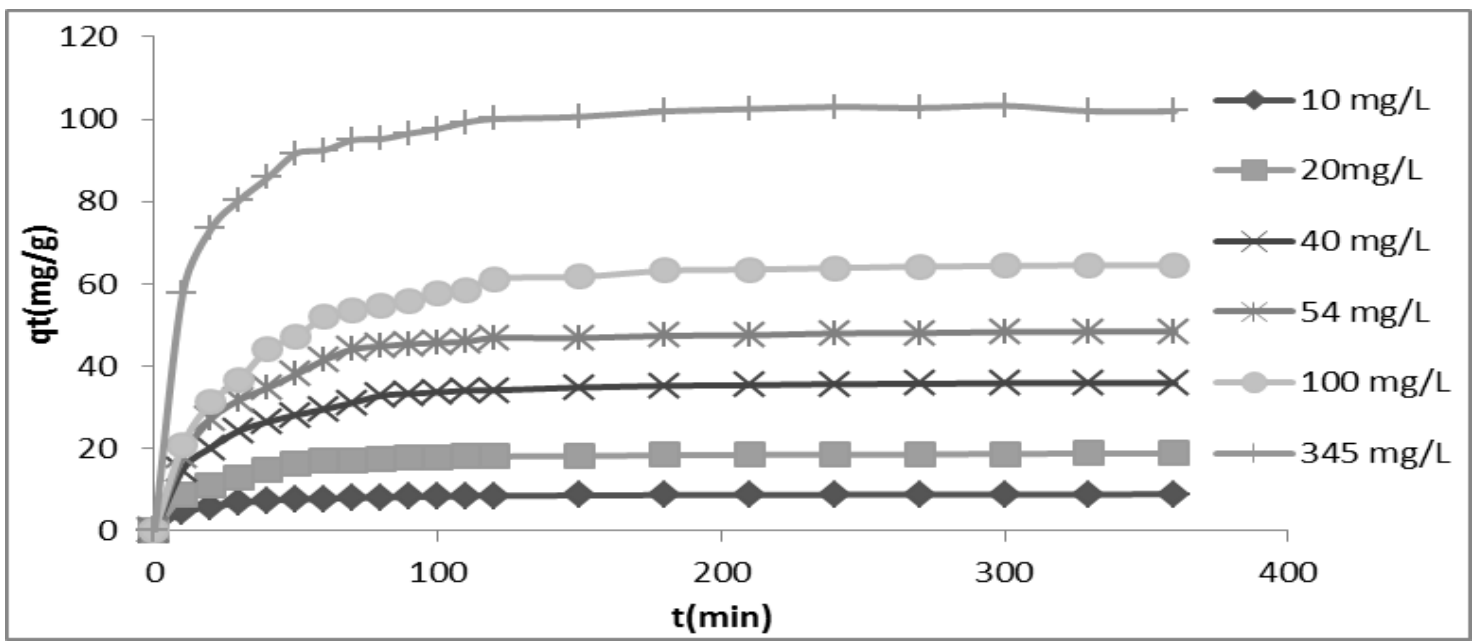

Figure 4: Effect of contact time on MB adsorption onto DAP at different initial concentrations 
The results (Figure 4) show that the amount of MB adsorbed $(\mathrm{mg} / \mathrm{g})$ increases when the initial concentration increases.The adsorption capacity after 6 hoursis $8.89,48.45$ and $103.27 \mathrm{mg} / \mathrm{g}$ for the initial dye concentration from 10,54 and $345 \mathrm{mg} / \mathrm{L}$ respectively. This can be interpreted by the increasing of concentration gradient between MB solution and adsorbent surface. More the solution concentration increases more the gradient increases and more adsorption is better.

\subsection{Adsorption isotherms}

In order to determine adsorption isotherms, experiments were carried out in the following conditions: MB solution volume is $1 \mathrm{~L}$, initial concentrations are $10,20,40,54,100$ and $345 \mathrm{mg} / \mathrm{L}, \mathrm{DAP}$ dose is $1 \mathrm{~g}, \mathrm{pH}$ is 6 , temperature is $20^{\circ} \mathrm{C}$, stirring speed is $400 \mathrm{rpm}$ and equilibrium time is 6 hours. Langmuir, Freundlich and Temkin constants and there related correlation coefficients were calculated and reported in Table 2.

The results showed that Langmuir fits better than the Freundlich and temkin equations with a $\mathrm{R}^{2}=0.998$.

The best fit of equilibrium data in the Langmuir isotherm expression predicts the monolayer coverage of MB onto DAP, without any interaction dye-dye. The maximum adsorption capacity of MB on DAP in the studied conditions is equal to $107.5 \mathrm{mg} / \mathrm{g}$. It is higher than some adsorbents capacities listed in Table 3.

Table 2: Constants of adsorption isotherms of MB onto DAP

\begin{tabular}{|l|l|l|l|l|l|l|l|l|l|}
\hline \multicolumn{2}{|l|}{ Langmuir } & \multicolumn{3}{l|}{ Freundlich } & \multicolumn{3}{l|}{ Temkin } \\
\hline qmax $_{\max }(\mathbf{m g} / \mathbf{g})$ & $\mathrm{K}_{\mathrm{L}}$ & $\mathrm{R}^{2}$ & $1 / \mathrm{n}$ & $\mathrm{n}$ & $\mathrm{K}_{\mathrm{F}}$ & $\mathrm{R}^{2}$ & $\mathrm{~A}$ & $\mathrm{~B}$ & $\mathrm{R}^{2}$ \\
\hline $\mathbf{1 0 7 . 5 2}$ & 0.091 & 0.998 & 0.398 & 2.509 & 15.258 & 0.827 & 1.773 & 16.92 & 0.984 \\
\hline
\end{tabular}

Table 3: Comparison of adsorption capacity of DAP with other low-cost adsorbents

\begin{tabular}{|l|l|l|}
\hline \multicolumn{1}{|c|}{ Adsorbent } & $\mathbf{q}_{\max }(\mathbf{m g} / \mathbf{g})$ & Reference \\
\hline Activated banana peel & 19.7 & {$[9]$} \\
Natural banana peel & 18.6 & {$[9]$} \\
Pomelo peel & 133.0 & {$[10]$} \\
Jackfruit peel & 285.7 & {$[11]$} \\
Potato peels & 33.5 & {$[12]$} \\
Palm kernel fiber & 95.4 & {$[16]$} \\
Wood apple shell & 95.2 & {$[14]$} \\
Tea waste & 85.2 & {$[21]$} \\
Dried Apple peel & 107.5 & This study \\
\hline
\end{tabular}

\subsection{Adsorption Kinetics}

In order to modelizeadsorption kinetics of MB on DAP, two kinetic models were tested.

4.6.1. Pseudo-first order model

The pseudo-first order model is expressed by the Lagergren equation [23]:

$$
\frac{d q_{t}}{d t}=K_{1}\left(q_{e}-q_{t}\right)(13)
$$

$\mathrm{q}_{\mathrm{e}}$ and $\mathrm{q}_{\mathrm{t}}$ are respectively the amounts of dye $(\mathrm{mg} / \mathrm{g})$ adsorbed at equilibrium and at time $\mathrm{t} . \mathrm{K}_{1}$ is the rate constant of the pseudo-first order $\left(\mathrm{min}^{-1}\right)$. After integrating and applying the initial conditions $\left(\right.$ at $t=0, q_{t}=0$ and $t=t_{e}, q_{t}$ $=\mathrm{q}_{\mathrm{e}}$ ), the equation takes the form:

$$
\log \left(q_{e}-q_{t}\right)=\log 0 q_{e}-\frac{K_{1}}{2,303} t(14)
$$

Figure 5 shows the presentation of the pseudo-first order model.

\subsubsection{Pseudo-second order model}

Adsorption data were also analyzed according to the kinetic model of the pseudo-second-order[24]:

$$
\frac{d q_{t}}{d t}=K_{2}\left(q_{e}-q_{t}\right)^{2}(15)
$$

$\mathrm{K}_{2}$ is the rate constant of pseudo-second order $(\mathrm{g} / \mathrm{mg}$. $\mathrm{min})$. After integrating and applying the conditions (at $\mathrm{t}=$ $0, \mathrm{q}_{\mathrm{t}}=0$ and $\mathrm{t}=\mathrm{t}_{\mathrm{e}}, \mathrm{q}_{\mathrm{t}}=\mathrm{q}_{\mathrm{e}}$ ), the equation takes the linear form:

$$
\frac{\mathrm{t}}{\mathrm{q}_{\mathrm{t}}}=\frac{1}{\left(\mathrm{~K}_{2} \mathrm{q}_{\mathrm{e}}^{2}\right)}+\frac{1}{\mathrm{q}_{\mathrm{e}}} \mathrm{t}(16)
$$

Figure 6 gives the presentation of the pseudo-second order model. 


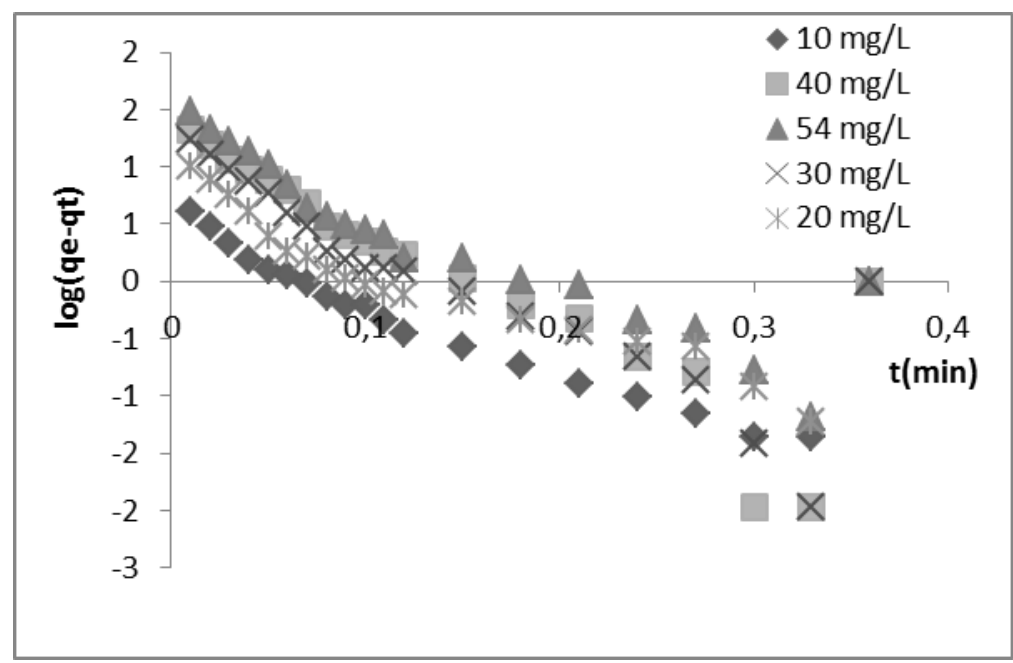

Figure 5: Pseudo-first order model of MB adsorption onto DAP

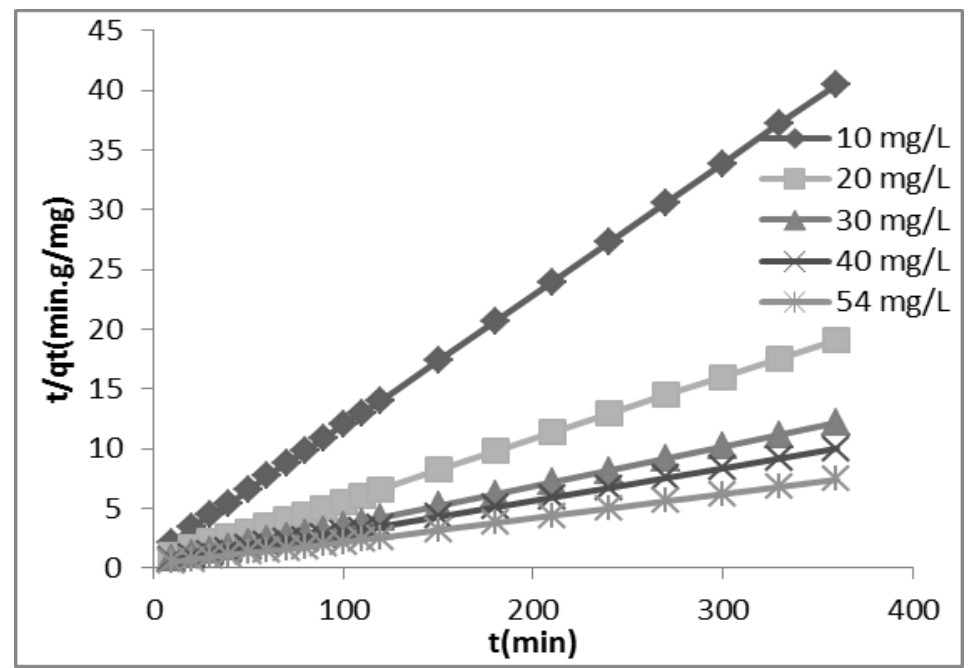

Figure 6: Pseudo-second order model

Results according to Figure 5 and Figure 6, show that the adsorption complies with a pseudo-second order equation. Indeed the $\mathrm{R}^{2}$ in this case is very near to 1 and the calculated $\mathrm{q}_{\mathrm{e}}$ values $\left(\mathrm{q}_{\mathrm{e}} \mathrm{cal}\right)$, in Table 4 , also agree with the $\mathrm{q}_{\mathrm{e}}$ experimental ( $\mathrm{q}_{\mathrm{e}} \mathrm{exp}$ ). These results indicate that the adsorption system studied belongs to the secondorder kinetic model.Several works on methylene blue bioadsorption have reported that the pseudo-second order model describes their results [25], [26].

Table 4: Kinetic parameters of MB adsorption on DAP at different initial concentrations

\begin{tabular}{|c|c|c|c|c|c|c|c|}
\hline \multicolumn{2}{|c|}{} & \multicolumn{3}{|c|}{ Pseudo 1 $^{\text {st }}$ order } & \multicolumn{3}{c|}{ Pseudo 2dorder $^{\text {nd }}$ Order } \\
\hline $\mathrm{C}(\mathrm{mg} / \mathrm{L})$ & $\begin{array}{l}\mathrm{q}_{\mathrm{e}} \exp \\
\mathrm{mg} / \mathrm{g})\end{array}$ & $\mathrm{K}_{1}\left(\mathrm{~min}^{-1}\right)$ & $\begin{array}{l}\mathrm{q}_{\mathrm{e}} \mathrm{cal} \\
(\mathrm{mg} / \mathrm{g})\end{array}$ & $\mathrm{R}^{2}$ & $\mathrm{~K}_{2}\left(\mathrm{~g} \cdot \mathrm{mg}^{-1} \cdot \mathrm{min}^{-1}\right)$ & $\begin{array}{l}\mathrm{q}_{\mathrm{e}} \mathrm{cal} \\
(\mathrm{mg} / \mathrm{g})\end{array}$ & $\mathrm{R}^{2}$ \\
\hline 10 & 8.90 & 0.009 & 1.31 & 0.6326 & 0.1055 & 9.15 & 1 \\
20 & 18.84 & 0.012 & 1.90 & 0.8429 & 0.0699 & 19.42 & 0.9997 \\
30 & 29.52 & 0.015 & 2.68 & 0.7601 & 0.0511 & 30.77 & 0.9995 \\
40 & 35.88 & 0.017 & 3.30 & 0.7728 & 0.0432 & 37.59 & 0.9996 \\
50 & 48.45 & 0.013 & 3.32 & 0.8320 & 0.0375 & 50.76 & 0.9993 \\
\hline
\end{tabular}

\subsection{Thermodynamic parameters}

The influence of temperature on the adsorption was studied in the range of 10 to $40{ }^{\circ} \mathrm{C}$. Figure 7 shows the variation of adsorption capacity $(\mathrm{mg} / \mathrm{g})$ of $\mathrm{MB}$ on the DAP according to the temperature. As we can see in Figure 7 the adsorption capacity decreased slightly from 9.08 to $8.56 \mathrm{mg} / \mathrm{g}$ when the solution temperature increases from 10 to $40^{\circ} \mathrm{C}$. Since the adsorption decreased when temperature increased, the system is considered to be exothermic. 
Thermodynamic parameters of adsorption were determined from the experimental results obtained at different temperatures using the following equations:

$$
\Delta \mathrm{G}^{\circ}=\Delta \mathrm{H}^{\circ}-\mathrm{T} \Delta \mathrm{S}^{\circ}
$$

$\mathrm{T}(\mathrm{K})$ is solution temperature

$$
\mathrm{K}_{\mathrm{d}}=\frac{\mathrm{q}_{\mathrm{e}}}{\mathrm{C}_{\mathrm{e}}}
$$

Where $K_{d}$ is the distribution coefficient, $q_{e}(\mathrm{mg} / \mathrm{g})$ is the adsorption capacity at equilibrium, $\mathrm{C}_{\mathrm{e}}(\mathrm{mg} / \mathrm{L})$ is the solution concentration at equilibrium.

The standard enthalpy $\Delta \mathrm{H}^{\circ}$ and entropy $\Delta \mathrm{S}^{\circ}$ can be determined from the following equation of Van't Hoff:

Where $\mathrm{R}$ is the universal gas constant.

$$
\ln \mathrm{K}_{\mathrm{d}}=\frac{\Delta \mathrm{S}^{\circ}}{\mathrm{R}}-\frac{\Delta \mathrm{H}^{\circ}}{\mathrm{RT}}
$$

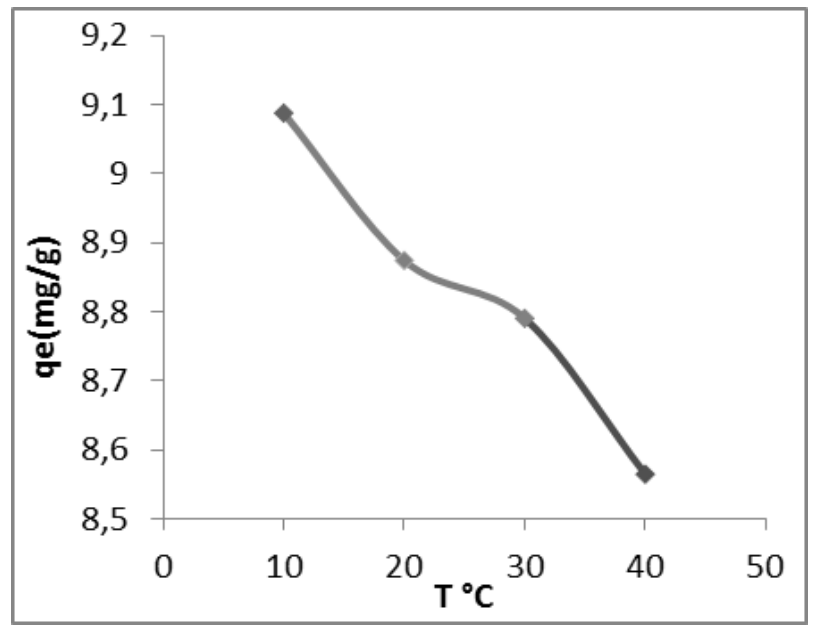

Figure 7: Effect of temperature on MB adsorption onto DAP

$\Delta \mathrm{H}^{\circ}$ and $\Delta \mathrm{S}^{\circ}$ were obtained from the slope and the intercept of the plot of $\mathrm{Ln}\left(\mathrm{K}_{\mathrm{d}}\right)$ as a function of $1 / \mathrm{T}$ respectively (Figure 8). Thermodynamic parameters are summarized in Table 5. The values of Gibbs free energy $\left(\Delta \mathrm{G}^{\circ}\right)$ of adsorption of MB adsorption on DAP were found to be negative corresponding to a spontaneous process [15]. The negative value of $\Delta \mathrm{H}^{\circ}$ confirms that adsorption phenomenon of MB on DAP is exothermic. The negative value of $\Delta \mathrm{S}^{\circ}$ indicates that the order of distribution of the dye molecules on the adsorbent is high compared to that in the solution. This also suggests the probability of a thermodynamically favorable adsorption [27].

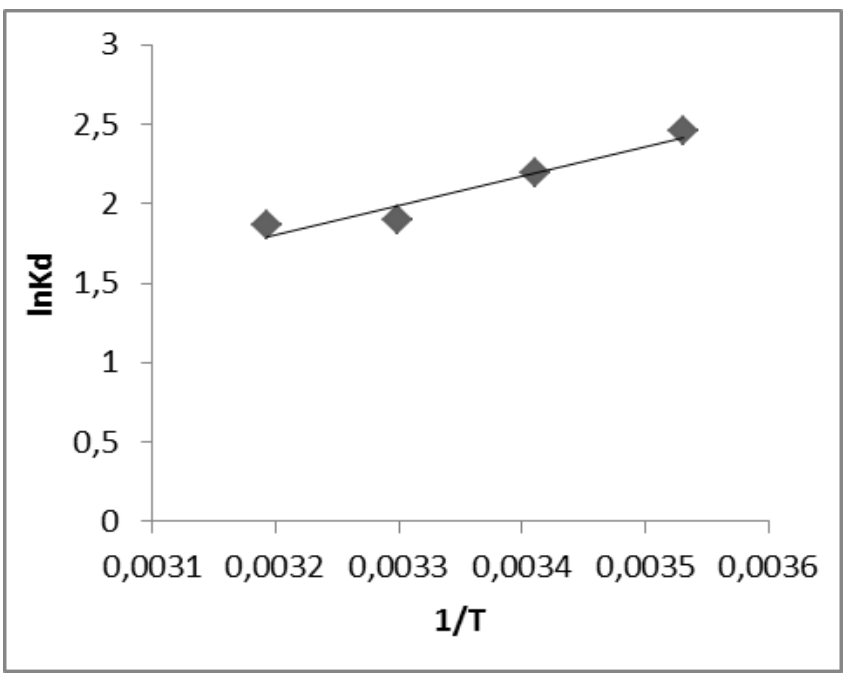

Figure 8: Van'tHoff plot for adsorption of MB on DAP 
Table 5: Thermodynamic parameters of MB adsorption on DAP

\begin{tabular}{|c|c|c|c|c|}
\hline $\mathrm{T}^{\circ} \mathrm{C}$ & $\mathrm{q}_{\mathrm{e}}(\mathrm{mg} / \mathrm{g})$ & $\Delta \mathrm{G}^{\circ}(\mathrm{Kcal} / \mathrm{mol})$ & $\Delta \mathrm{S}^{\circ}(\mathrm{Kcal} / \mathrm{K} . \mathrm{mol})$ & $\Delta \mathrm{H}^{\circ}(\mathrm{Kcal} / \mathrm{mol})$ \\
\hline 10 & 9.0877 & -1.3609 & & \\
\cline { 1 - 3 } 20 & 8.8981 & -1.2794 & \multirow{2}{*}{-0.0082} & \multirow{2}{*}{-3.6706} \\
\hline 30 & 8.7902 & -1.1978 & & \\
\hline 40 & 8.5646 & -1.1162 & & \\
\hline
\end{tabular}

\section{Conclusions}

Adsorption of Methylene blue on Dried Apple Peel has been studied. Adsorption experiments were carried out as a function of contact time, dye concentration, adsorbent dosage, temperature and solution $\mathrm{pH}$.

$\mathrm{MB}$ adsorption capacity increased with the increasing of initial dye concentration and with the increasing of adsorbent dose until $2 \mathrm{~g}$. It increased with the increasing of $\mathrm{pH}$ and decreased when the temperature increased.

The adsorption data was well described by the Langmuir isotherm equation with a maximum adsorption capacity of $107.52 \mathrm{mg} / \mathrm{g}$, a satisfying result in comparison with other bioadsorbents, moreover the peels are used without any treatment. The kinetics followed the pseudo-second order model.The thermodynamic parameters obtained show that the adsorption of the MB on DAP is spontaneous and exothermic

The present study concludes that Dried Apple peel could be employed as a low-cost adsorbent for the removal of methylene blue and can be a promising bioadsorbent for the elimination of other pollutants.

\section{References}

1. Ben Mansour H., Boughzala O., Dridi D., Barillier D., Chekir-Ghedira L., Mosrati R., J. Water Sci. 24(3) (2011) 209-238.

2. Hao O. J., Kim H., Chiang P.C., Crit. Rev. Env. Sci. Technol. 30 (2000) 449-505.

3. Juang R.S, Wu F.C., R.L. Ts., Eng. Env. Technol.18 (1997) 525-531.

4. Njoya D., NdiNsami J., Ntieche Rahman A., Lekene Ngouateu R. B., Hajjaji M., Nkoumbou C., J. Mater. Environ. Sci. 8(5) (2017) 1803-1812.

5. Mahammedi F., Benguella B., J. Mater. Environ. Sci. 7 (1) (2016) 285-292

6. Amrhar O., Nassali H., Elyoubi M. S., J. Mater. Environ. Sci. 6 (11) (2015) 3054-3065

7. Lafi R., Rezma S., Hafiane A., Desalin. Water Treat. (2014) 1-12.

8. Do Nascimento G.E., Duarte M.M.M.B., Campos N.F., Barbosa C.M.B.D.M., Da Silva V.L., Desalin. Water Treat. 52 (2014) 1578-1588

9. Khalfaoui A., Meniai Abdeslam H., Derbal K., Energy Procedia. 19 (2012) 286-295.

10. Hou S.X., Adv. Mater. Res. 634-638 (2013) 178-181

11. Hameed B.H., J. Hazard. Mater. 162 (2009) 344-350

12. Oktem Y.A., Soylu S.G.P., Aytan N., J. Sci. Ind. Res. 71 (2012) 817-821

13. Djelloul C., Hamdaoui O., Desalin. Water Treat. (2014) 1-10.

14. Akkaya G., Güzel F., Chem. Eng. Commun. 201 (2013) 557-578.

15. Jain S., Jayaram R.V., Desalin. 250 (2010) 921-927

16. El-Sayed G.O., Desalin. 272 (2011) 225-232

17. Langmuir L., J. Am. Chem. Soc. 40 (1918) 1361-1403.

18. Freundlich H., Colloid and capillary chem. Metheum. London, (1926)

19. Limousin G., Gaudet J.P., Charlet L., Szenknect S., Barthes V., Krimissa M., Appl. Geochem. 22 (2007) 249-275

20. Gimbert F., Crini N.M., Renaut F., Badot P.M., Crini G., J. Hazard. Mater. 157 (2008) 34 - 46.

21. Uddin Md. T., Islam Md. A., Mahmud S., Rukanuzzaman Md., J. Hazard. Mater. 164 (2009) 53-60

22. Uddin Md. T, Rukanuzzaman Md., Maksudur Md.R. K., Akhtarul Md.I., J. Env. Manag. 90 (2009) 3443-50

23. Lagergren S., Zurtheorie der sogenannten adsorption gelosterstoffe, Kungliga Svenska Vetenkaps akademiens, Handl. 24 (1898) 1-39.

24. Ho Y.S., Mckay G., Process Biochem. 34 (1999) 451-465.

25. Tsai W.T., Hsu H.C., Su T.Y., Lin K.Y., Lin C.M., Dai T.H., J. Hazard. Mater. 147 (2007) 1056-1062.

26. Dogan M., Ozdemir Y., Alkan M., Dyes Pigments 75 (2007) 701-713

27. Mahjoub B., Ncibi M. C., Seffen M., Can. J. Chem. Eng. 86 (2008) 23-29 